\title{
A Narrative Research on Affordances for EFL Student Teachers' Learning-to-Teach Beyond the Classroom*
}

\author{
ZENG Zheng-ping \\ Leshan Normal University, Leshan, China
}

\begin{abstract}
To become a qualified EFL (English as a Foreign Language) student teacher who can take an English teaching job in primary or high school after graduation, he or she must learn and use teacher knowledge inside and outside the classroom. Adopting a narrative research, this paper discusses eight excellent EFL student teachers' perception of affordances for learning to teaching beyond the classroom based on the theories of affordance and niche. The results show that perceiving many affordances for learning to teach in their niches is of great significance for student teachers to improve their teaching competence. To make student teachers become qualified, we teacher trainers should not ignore the importance of learning-to-teach beyond the classroom.
\end{abstract}

Keywords: student teacher education, learning-to-teach, affordance, niche, beyond the classroom

\section{Introduction}

Much as a traveler in a new country takes in a landscape, so also do EFL student teachers take in the disparate elements of learning to teach today (Costigan, 2014). In this sense, the environment in which student teachers learn to teach can be viewed as a unique habitat, ecosystem, or ecology. What is ecology? According to Lier (2004), ecology studies organisms in their relations with the environment and the environment includes all physical, social, and symbolic affordance that provides grounds for activity. Meanwhile, ecology favours studies conducted in a natural environment and not in isolation (Menezes, 2011), and it takes account of the full complexity and interrelateness of processes that combine to produce an environment (Lier, 2004). As a consequence, there is a shift from the classroom to the other social contexts beyond the classroom. The ecological approach offers a new metaphor for understanding learning-to-teach beyond the classroom. The ecological perspective primarily uses ethnographic and qualitative methodology, in particular exploring the narratives or stories people create to make sense of the world and to create meaning (Costigan, 2014). Based on affordance and niche, this paper conducts a narrative research to investigate affordances for eight excellent EFL student teachers' learning-to-teach beyond the classroom. The term of "excellent student teachers" is defined by the teaching jobs that student teachers can easily find in the fourth year of the university. As we know, in current years it is really difficult for Chinese EFL student teachers to find jobs as English teachers when they graduate, especially good jobs. The research results can not only show the problems in learning to teach, but also reveal the root of the

\footnotetext{
* Acknowledgements: This research is financed by the Research Projects of Education Department of Sichuan Province (No.17SB0172) and Teacher Education Research Center of Sichuan Province (No.TER2014-009).

ZENG Zheng-ping, lecturer, M.A., School of Foreign Languages, Leshan Normal University, Leshan, China.
} 
problems. Moreover, this paper presents the strategies which optimize the learning-to-teach environment, aiming at providing beneficial suggestions for deepening the reform of student teacher education.

\title{
Affordance and Niche
}

\begin{abstract}
Affordance
According to Gibson (1986), the term affordance points to how an animal (or a person) perceives what one object in the environment affords (or provides) and acts upon it, and the object directly indicates one's relationship between the animal (or the person) and its environment. For example, a man wants to cross a creek and sees a flat rock rising above the water. By perceiving the rock's "stepping-on" function, he steps on it and gets across the creek. Affordance perceiving is closely related to one's talent, interest, capacity, etc. (WU \& LI, 2009). Thus, unlike the man, a child might not perceive the same helpfulness of the rock due to his short legs and limited balancing capacity or cognitive ability. Besides, affordance assumes an active learner's establishing relationships with and within the environment (Lier, 2004) and those connections are crucial for learning opportunities to emerge. In recent years, the notion of affordance has expanded into different sub-categories, such as natural and cultural affordance (Reed, 1988), conversational affordance, and linguistic affordance (Lier, 2004). In the realm of student teachers' learning-to-teach, we can define it as educational affordance and it indicates a relationship between a student teacher and the environment. The affordance picked up will serve the student teacher to promote teacher learning action and lead to higher levels of interaction. The educational affordances are only available to active student teachers who may pick one or more of the affordances within the environment. For example, a student teacher does not know how to present new vocabulary when he plans his lesson, an active learner might find the answer from the resources which have the function "offering the ways to present new vocabulary", such as a teacher trainer, a partner, an English teacher in a school, a video of language teaching, an English teaching journal, a book named Teaching Methodology Made Easy, and so on. By perceiving the function of any of the above mentioned resources, the student teacher might have the action "learning how to present new vocabulary". The student teacher has learned the ways to present new vocabulary by reading the book named Teaching Methodology Made Easy, but he still might present the new vocabulary in an inappropriate manner in simulation teaching. If a teacher trainer demonstrates the way of presentation, the student teacher will probably present the new vocabulary in a good manner because he perceives the information (an affordance for locomotion or proper behavior) from teacher trainer's demonstration. There are many educational affordances within the environment. But the same environment perceived by different observers may produce different perceptions of affordances, which are determined by the culture, social setting, experience, and intentions of the observer (McGrenere \& Ho, 2000). Affordance is just a kind of potential meaning and possibility and it implies certain potential behaviors (Lier, 2004). For educational affordances, they can be divided into human resources and material resources. The human resources could be teacher educator, trainer, teachers in school, classmates, or schoolmates; the material resources (cultural products) could be books about language teaching, English language teaching journals, teaching videos, or language teaching TV programs. If a student teacher's teaching competence has improved, he or she must take in sufficient resources from the environment, take a superior position in the niches, or gain sufficient opportunities to enlarge their niches.
\end{abstract}


Niche

Niche is another key concept in ecology, it has to do with the relational position of an individual in its ecosystem (Menezes, 2011). As Gibson (1986) put it:

There are all kinds of nutrients in the world and all sorts of ways to getting food; all sorts of shelters or hiding places; all sorts of materials for making shelters, nests, mounds, huts; all sorts of locomotion that the environment makes possible. These offerings have been taken advantages of: The niches have been occupied. But there may be many offerings of the environment that have not been taken advantages of, that is, niches are not yet occupied. (Gibson, 1986, p. 129)

Based on Gibson's point of view, there are all kinds of "learning to teach" resources in the normal university and the city in which the student teachers live and all sorts of ways to get teacher knowledge; all sorts of materials for lesson planning, classroom management, speaking teaching, listening teaching, reading teaching, writing teaching, assessment, and so on; all sorts of human resources that student teachers can interact with; all sorts of space for teaching practice that the environment makes possible, such as classroom, library, primary schools, English training schools, or the family who needs English private tutors. These offerings have been taken advantages of: The niches have been occupied. From the example, we know a niche is a position in an ecosystem that affords an organism the resources it needs to survive (Ramstead, Veissière, \& Kirmayer, 2016) and it is a set of affordances that are available to organisms in a given environment at a given time (Gibson, 1986; Ramstead, Veissière, \& Kirmayer, 2016). From the above, niche in learning-to-teach realm can be viewed as an environment mediated by teacher knowledge (affordances), a place where a student teacher acts by using the teacher knowledge, or a student teacher's position in a teacher learning community. For the position in the community, it means a student teacher has to coexist with other learners and sometimes compete for his or her position in the niche so that he or she can survive in his or her niche. It is obvious that the resources in the classroom are not sufficient for a student teacher to gain enough teaching knowledge and skills, so he or she must look for learning-to-teach affordances beyond the classroom.

\section{Affordances in Teacher Learning Niche}

Taking into account the idea of niche as a position in an ecosystem that affords an organism the resources it needs to survive, EFL student teachers must belong to a place where they can find "learning-to-teach" affordances. This part will report eight excellent student teachers' learning-to-teach experiences during the first three years in university.

In a context of one normal university, EFL student teachers can find different affordances for learning-to-teach in their niches to improve their teaching competence. In excerpt (1) and (2), both student teachers find their teacher trainers as affordances for learning-to-teach.

(1) Student A: I want to be an English teacher when I graduate from my university. Last semester (the second year), Mr ZENG taught us the course Comprehensive English, in this course he always designed some interesting and valuable activities which were quite different from the activities designed by my previous English teachers. Besides, Mr ZENG still has taught English in junior and senior schools for five years and he's now teaching some children English. His teaching beliefs and teaching experiences make me have the idea of learning how to teach from him. After telling Mr ZENG my intention, he is pleased to accept me as his teaching assistant. As an assistant, I am supposed to prepare some realia. For example, I've made some masks for the Halloween 
lesson, some pictures for teaching numbers, homemade clock for teaching time. Before making these realia, $\mathrm{Mr}$ ZENG would like to tell me the activity he is going to organize and the purposes of the realia. While helping him, I begin to construct my own teaching beliefs, I think it's a good way to learn how to teach, it is more practical compared with the learning in English methodology course.

(2) Student B: In the third semester I have taken the course, English Teaching Strategy. In this course, my teacher Mr DENG always shared many English teaching episodes with us. Mr DENG is a professor who have been taught English methodology for more than 20 years and he's still engaged in in-service teacher training. I think I cannot get sufficient knowledge from him in class, so I always keep contact with him beyond the classroom. For example, while preparing a lesson plan one day, I had no ideas of leading in the topic of the lesson, I found the time to discuss with Mr DENG. He first told me the principles for introducing the topic, then asked me to analyze the teaching content, and guided me to figure out the way to introduce the topic. During this process, I became much more clear about how to introduce a topic, but I don't have the time to discuss with my teaching in class in details. So I think keeping in contact with my professor after class is a really good way to learn to teach.

Affordances are relations of possibility between animals and their environments (Neisser, 1987) and they consist in the opportunities for interaction in the environment. Both student teachers perceive experienced teacher trainers as affordances for learning to teach. Student A gets the opportunity to prepare some realia used in the teaching. Mr ZENG tells student A why and how to use the realia. By perceiving the information (affordance), student A constructs her own teaching belief. Student B perceives many affordances from the professor for preparing a lesson plan. No matter Student A or B, both perceive their teachers as educational affordance. While interacting with their teachers, they can still perceive many direct affordances for improving their language teaching competence.

Student teachers who mainly learn to teach in the university belong to niches which provide limited affordances for learning-to-teach. But some student teachers try to enlarge their their niches by entering some schools or creating a teacher learning community where more affordances are available.

(3) Student C: In methodology course, the teacher Miss LI always teaches us some theories about language teaching and learning. I know these theories are very important, but they are really boring. To get more practical teaching knowledge instead of so many teaching theories, I have the idea of entering the real English classes in high school. Having this idea in mind, I tried to contact different schools, and finally the principal in No. Five Middle school accepted me as an intern student and he still assigned me an English teacher as my instructor. After getting the opportunity, I came to the school once a week when I didn't have lessons in my university. Each time I went to the school, I did some classroom observations, and my instructor told me her teaching beliefs sometimes, and she also asked me to correct students' homework sometimes. From my observation and correction of the students' homework, I've learned some practical knowledge which is difficult to learn in my university methodology courses.

(4) Student D: In the English methodology class, I am very happy to discuss how to teach with my classmates and the teacher. However, 45 minutes in class is not sufficient for us to discuss deeply, so I decide to construct a teacher learning community which consists of my methodology teacher and classmates who are deeply interested in teaching. With the help of my methodology teacher, I hold one activity once a week by the way of workshop and the time duration is a whole morning or afternoon which may be around four hours. In the 
workshop, we discuss how to teach language knowledge (vocabulary, phonetics, grammar) and language skills by using the primary school English textbooks.

Notions, such as relations, possibility, opportunity, and immediacy, can be used to indicate affordance which is what is available to the person to do something with (Lier, 2004). Student C perceives the school as affordance for learning to teach and she initiates contacting principals in some schools. On the contrary, instead of finding the learning opportunities in some schools, Student D constructs her own learning community in which there are a group of people she can learn from. During the workshop, all the community members can perceive affordances for teacher knowledge from each other. In order to survive or emulate others, a student teacher must take an active attitude of occupying enough useful resources so as to enlarge his/her niche, coexist with others, and sometimes compete for his/her position in the niche.

Niche is a place to act by using the teacher knowledge. A student teacher who assumes the position of a language teacher is expected to be successful in his attempt to use teacher knowledge in real teaching practice. Being aware of their roles as an English teacher in the future, Student E and F try to find opportunities to teach English in some English training schools.

(5) Student E: In methodology class, I've learned a lot of teacher knowledge. However, having the knowledge is not enough for me to be a good teacher in the future. I have to use the knowledge so as to improve my teaching skills in real teaching. Starting from this point, I try to look for a part-time job in some training schools. Unfortunately, no training school wants me for the lack of teaching experience at first. Finally, a training school accepts me for not paying me any wage. Although I cannot get any money from my work, I've really got a lot of teaching experiences which cannot be learned from my methodology teacher or any books. Thanks for the unforgettable teaching experience, I can find a good job when I graduate.

(6) Student F: On the one hand, my family is poor and my parents cannot support me financially each month; on the other hand, I want to work in a training school where I can use the teacher knowledge I've learned in methodology class. Therefore, I find a teaching job during both winter and summer vocation. Last summer, I taught primary school students English (Grade 3). During this period, I've learned a lot of things from my teaching. For example, it's really difficult for the young learners to remember the sounds of the new vocabulary. Before using the words to communicate, the pupils are supposed to do some listening activities, such as "listen and act", "listen and draw", "listen and touch", and so on. To conclude, I've learned a lot of teacher knowledge from my teaching which is more useful than some knowledge I learn from the books.

Affordances for language teacher knowledge are not the properties of the niches, but emerge from language teaching practice. In their teaching practice, there are lots of different possibilities or opportunities (affordances) for learning to teach. Both Student E and Student F have perceived affordances for teacher knowledge in their classrooms. Compared with student teachers who only learn how to teach in class, Student E and F have occupied more resources. The more resources they occupied, the larger their niches would become. As a consequence, their teaching competence would improve greatly.

Affordances are around learners and it is up to the learners to perceive what the niches offer them and act (Menezes, 2011). Some student teachers also look for cultural products, such as books, videos, journals, or Internet for teacher learning. They act by reading books and English journals, by watching videos about language teaching, or by surfing the Internet for some teaching activities or games. 
(7) Student G: This term, I found a part-time job in a training school. During my teaching, I always met some problems. To find the solutions to the problems. I preferred to read some teaching journals in the library than ask the teacher for help. Therefore, reading journals in the library is part of my university life. While reading, I also like taking some notes, as you know, we student teachers are not allowed to lend the journal in my university. From the journals, I can always find the solutions to the problems I encountered in my teaching.

(8) Student H: There are many ways to learn to teach. I would rather learn teacher knowledge from books than my teachers. Our methodology teacher recommends us many books about teaching, such as Interpretation of Reading Materials, Teaching Grammar Through Communicative Activities, How to Teach Sounds in Primary School, and so on. By reading these books, I can learn a lot of teacher knowledge which really helps me write a good lesson plan. For example, from the book Interpretation of Reading Materials, I know we can analyze one reading material from the perspective of language knowledge, language skill, genre, and culture.

Different places of a habitat may have different affordances. The observer may or may not perceive or attend to the affordance, according to his needs. For Student G, he perceived the journals as the affordance for looking for the solutions to the problems. Language teaching affordances are not the same for every learner. Student $\mathrm{H}$ perceived books as affordances for learning to teach.

\section{Conclusion}

Student teachers' learning-to-teach is discussed from an ecological perspective in this paper. By conducting a narrative research which is contextualized, I find the main reason why some student teachers are more excellent than others is that they find more affordances or learning opportunities for learning-to-teach beyond the classroom. Achieving a fit between the environmental properties and the possibilities for learning will guarantee the improvement of student teachers' teaching competence. For the eight student teachers, two have perceived the human resources as affordances for learning to teach, two have enlarged their niches by entering into some schools or creating a learning community, two have clearly realized their roles as student teachers and found opportunities to use the teacher knowledge they have learned in classroom, and the last two have perceived the function of books and teaching journal "offering teacher knowledge". Moreover, the premise of successful perception of different affordances for learning to teach is to be active. One main feature of all the excellent student teachers is that they are really active and they have strong motivations of learning to teach.

In this new era, we are experiencing a reform of student teacher education, which leads to the great change in learning-to-teach environment. To be specific, there emerge different courses related to teacher education, such as Interpretation of Standards for National Curriculum, Foreign Language Teaching Approaches Abroad, Teaching Assessment, Micro-teaching, and so on. It is obvious that the focus is more on what student teachers can learn in the classroom than what students can learn beyond the classroom. Therefore, this research can draw inspiration to the reform of student teacher education. From the perspective of affordance and niche, we should create an environment in which EFL student teachers can perceive more affordances for learning to teach and enlarge their niches by occupying as many affordances as possible. Affordances are around learners and it is up to the learners to perceive what the niches offer them and act (Menezes, 2011). Meanwhile, there are both positive and negative affordances, so we should try to make student teachers perceive the positive ones. 


\section{References}

Costigan, A. (2014). Ecological perspectives of learning to teach: Introduction to a special issue of teacher education quarterly. Teacher Education Quarterly, 1, 3-8.

Gibson, J. J. (1986). The ecological approach to visual perception. Hillsdale, NJ: Lawrence Erbaum.

Lier, L. V. (2004). The ecology and semiotics of language learning: A social cultural perspective. Boston: Kluwer Academic Publishers.

McGrenere, J., \& Ho, W. (2000). Affordance: Clarifying and evolving a concept (pp.179-186). Proceedings of Graphics Interface 2000 Conference. Montreal, Canada: Lawrence Erlbaum Associates Press.

Menezes, V. (2011). Affordances for language learning beyond the classroom. In B. Phil and R. Hayo (Eds.), Beyond the language classroom. Hampshire, England: Palgrave Macmillian.

Neisser, U. (1987). From direct perception to conceptual structure. In U. Neisser (Ed.), Concepts and conceptual development: Ecological and intellectual factors in categorization. Cambridge: Cambridge University Press.

Ramstead, M., Veissière, S. P. L., \& Kirmayer, L. J. (2016). Cultural affordances: Scaffolding local worlds through shared intentionality \& regimes of attention. Frontiers in Psychology, 7, 1090.

Reed, E. S. (1988). James J. Gibson and the psychology of perception. New Haven, CT: Yale University Press.

WU, W., \& LI, S. (2009). Views on ecological language teaching: A social cultural perspective. Shangdong Foreign Language Teaching, 30(6), 48-53. 